\title{
HOUSEHOLD BARGAINING, FINANCIAL DECISION-MAKING AND RISK TOLERANCE
}

\author{
Selamah Abdullah Yusof* \\ International Islamic University Malaysia
}

\begin{abstract}
This study examines the financial investment decision-making and risk behaviors of Malaysian men and women. It uses data obtained from a survey of employed Malaysians to test two opposing models of household decision making, the income pooling hypothesis and the bargaining model. Ordinal probit regressions are estimated to determine if earning share affects decisions on financial investments, and to identify factors that affect risk tolerance of men and women. The results indicate that although both men and women practice autonomy in decisions related to financial investments, women have lower risk tolerance than men. The results on decision making are consistent with the bargaining model as reflected in the importance of relative earning share in financial decision making.
\end{abstract}

Keywords: Malaysia; Income Pooling Hypothesis; Bargaining Model; Financial DecisionMaking; Risk Tolerance; Household.

\section{INTRODUCTION}

Malaysia has seen significant changes in terms of its demographics as well as the role played by the different segments of its community. In particular, there are increasing numbers of women who have large amounts of disposable income resulting from their move into professional occupations once defined as exclusively male. Although the women labor force participation rate has been fluctuating over the years ${ }^{1}$, the difference between the male and female ratio of employment to population has decreased from 34.5 in 2001 to 31.5 in 2009 (Malaysia Department of Statistics, 2010). This means that there is a relative increase in the number of women in employment to that of men since the ratio of women population to total has remained around 49.4 percent in the period of 2001 to 2009 (Malaysia Department of Statistics, 2008, 2010).

In addition, a larger proportion of women are working more than 40 hours per week than before (77.0 percent in 2001, and 80.2 percent in 2009). Furthermore, among those in the labor force, women outperformed men in terms of educational attainment. In 2001, 18.2 percent of

\footnotetext{
* Corresponding author: Department of Economics, International Islamic University Malaysia, Jalan Gombak 53100, Kuala Lumpur, Malaysia.E-mail: selamah@iium.edu.my; Telephone: 603-6196 4615/4649; Fax: 603-6196 4850

1 Labor force participation rates for women are 46.8, 45.9 and 46.4 percent, respectively for 2001, 2005 and 2009 (Malaysia Department of Statistics, 2010).
} 
the women in the labor force have tertiary education compared to 13.8 percent that of men in the labor force. The difference is more significant in 2009, where the percentages are 29.9 and 19.7 for women and men, respectively (Malaysia Department of Statistics, 2010). The increased level of educational achievement has made more occupations available to women, and enabled them to compete with men on a more equal footing. How do these developments affect the household financial decision-making process, and the level of risk tolerance of women relative to that of men?

The objective of this paper is two-fold. The first is to test two opposing models of household behavior which are the income pooling hypothesis and the bargaining model, by examining the financial investment decision-making of employed married men and women in Malaysia. The second objective is to examine women and men's behavior towards risk based on the data of employed Malaysians, both married and unmarried. This paper also investigates if the effects of socioeconomic factors are different between those who are married and unmarried, and between women and men.

The data that is used in this study is obtained from a survey that is collected at the individual rather than household level. Thus it is not hampered by measurement issues that some empirical studies faced which used household data to make inferences on intra-household decision making and allocation process (Doss, 1996). The survey approach also allows controlling for a larger set of variables that have been revealed to be potentially relevant in earlier studies on decision making and risk tolerance (Beckmann and Menkhoff, 2008).

This study focuses on the final stage of the decision making process, that is on the final decision. As accepted in many studies on decision making (such as Webster, 1994; Ford et al., 1995; Martinez and Polo, 1999), there are two earlier stages in the process, which are problem recognition and search for information, as proposed by Davis and Rigaux (1974). Though these two stages are essential, the final decision stage is one which determines the actual financial investment.

\section{HOUSEHOLD DECISION-MAKING MODELS AND RISK-TOLERANCE BEHAVIOR}

In modeling household decision-making process, most literature usually discussed two main approaches of modeling which differ with regards to whether the sources of income should affect patterns of financial investment (Phipps and Burton, 1998). The household utility function framework assumes that a family maximizes a single household utility function reached by a consensus among family members subject to a pooled resource constraint. It does not differentiate between individual family members, nor does it recognize any systematic differences in power relations among household members (Becker, 1974, 1981; Samuelson, 1956). This model predicts that the outcome and the decision-maker are independent of who earns the income in the household. Participation in decision-making process and relative share of income are not related to one another (Bernasek and Bajtelsmit, 2002).

The other approach, namely the bargaining model incorporates divergent and conflicting preferences of individual family members into the analysis. Papers such as Lundberg et al. 
(1997), Phipps and Burton (1998) and Bernasek and Bajtelsmit (2002) discuss variations of the bargaining model that have been developed by various researchers such as Manser and Brown (1980), McElroy and Horney (1981) Lundberg and Pollak (1993) and Kanbur and Haddad (1994), among others. Bargaining power of a household member is expected to be positively related to relative access to income, education and paid work outside the home and this leads to a greater participation in the decision-making process (Jianakoplos and Bernasek, 2008).

In testing the two opposing models, many studies examine the influence of spouse in decisionmaking. The findings of some studies support the bargaining models as it is shown that changes in economic features of a household lead to transformations in decision-making patterns and financial investment behaviors and outcomes. The contribution to the household income influences the level of control and power in making financial decisions of the household, in particular for the wife (see for example, Lee and Beatty, 2002; Burgoyne and Morison, 1997; Laurie and Rose, 1994; Goode et al., 1998; Pahl, 1995, 2000; Vogler and Pahl, 1993, 1994; Yilmazer and Lyons, 2010; Malone et al., 2010).

Other studies, however, found support for the pooling theory of household behavior which assumes a unitary household utility function. Commuri and Gentry (2005), Tichenor (1999) and Blumstein and Schwartz (1983) found no strong evidence on the impact of resources a spouse possess, such as education, income and occupation, on family purchase decisionmaking. Jianakoplos and Bernasek (2008) also showed that there was limited support for relative income shares of spouses having an effect on financial decision making, in particular, on household financial risk taking.

Pertaining to risk tolerance of women, most studies have shown that women are more risk averse than men. Bruce and Johnson (1994), Jianakoplos and Bernasek (1998), Lewellen et al. (1977), Sunden and Surette (1998), Hinz et al. (1997) and Al-Ajmi (2008) determined that women take less financial risk than men. However, Schubert et al. (1999) in their experimental study contended that comparative risk propensity of men and women are strongly dependent on the financial decision setting. Findings suggesting gender-specific risk behavior as found in survey data might be due to differences in male and female opportunity sets rather than stereotypic risk attitudes.

However, it has been argued that behavior in abstract gambling experiments, although provides stronger control of the economic environment in which decisions are made, may not correspond to risk behavior in contextual decisions (Hershey and Schoemaker, 1980). Taking this factor into account, Dwyer et al. (2002) examined risk-taking in mutual fund investments across gender types while controlling for investor-specific financial investment knowledge. Along the same line, Beckmann and Menkhoff (2008) conducted a survey among professional fund managers to analyze differences between women and men in their behavior towards risk. This group of individuals had familiarity with risk, and risk decision under financial framing. They showed that women were more risk averse than men, where female fund managers shy away from competition. Dwyer et al. (2002) findings also suggested that women take less risk than men in their mutual fund investments. However, the observed difference in risk taking 
was significantly reduced when financial investment knowledge was included as a control variable.

As explained by Schubert (2006) based on earlier studies (Estes and Hosseini, 1988; Stinerock et al., 1991; Zinkhan and Karande, 1991; Lundeberg et al., 1994; Beyer and Boweden, 1997; Barber and Odean, 2000; Gervais and Odean, 2001), a dominant finding with respect to individual characteristics is that in decision making under risk men are more confident and more overconfident than are women. As a consequence, men tend to take higher risks than women. She further argued that men typically focus on the probability of likelihood component of risks, whereas women focus on future consequences. However, Beckmann and Menkhoff (2008) applied three measures of overconfidence which were overoptimistic self-assessment, illusion of control, and miscalibration, and found that women were not less overconfident than men. Yet, their results indicated that women have lower risk tolerance than men.

\section{SAMPLE AND DATA}

The data that is used in this study is obtained from a survey conducted from November, 2007 to February, 2008 for a bigger project to determine the expenditure and investment patterns of Malaysians. The participants of the survey consisted of employed Malaysians, working in various parts of the country and representing various segments of the society. Several stages of stratified sampling procedure was carried out, firstly, based on the regions and states in Malaysia, followed by urban and non-urban areas, and finally based on economic sectors.

Several states and a territory were chosen to represent various regions in Malaysia, which were Kedah (northern), Kelantan (eastern), Selangor (central), Johor (southern) and Kuala Lumpur (capital city) of Peninsular Malaysia and Sarawak (East Malaysia). Within each state, with the exception of Sarawak, at least one urban (or more urban) and one rural (or less urban) area were selected. For Sarawak, the survey was conducted in its capital city. ${ }^{2}$

Selections were then made within the economic sectors. Based on the proportion of population of the various states, of urban and rural, and of various sectors in the economy, the target size of each sub-sample was determined accordingly. For the non-agriculture private sector, most of the companies were randomly selected from the list given in the Yellow Pages. ${ }^{3}$ Others were randomly chosen from Times Business Directory of Malaysia 2004. ${ }^{4}$ In the case of the public sector, random selections of the organizations were made from a list of government institutions located in the selected areas. Employees from various occupational levels of the selected companies and government organizations were then selected to be included in the

\footnotetext{
2 For each region, the state was chosen based on which one best represent the region. While some states that were chosen have higher proportions of certain ethnic groups compared to the national average, others would be otherwise. For example, Kedah and Kelantan would have higher percentages of Malays, while Kuala Lumpur and Selangor have higher percentages of Chinese, relative to the national average. Thus, the three main ethnic groups should be appropriately represented, at least, theoretically. (http://www.epu.gov.my/populationandlabourforce).

http://www.yellowpages.com.my.

4 We rely more on the Yellow Pages for the selection since the information of the companies listed were more current. Information on companies listed in Times Business Directory was somewhat outdated.
} 
survey. For the agricultural sector, a list of associations of farmers and another of fishermen were obtained from various official institutions. The associations were randomly chosen and then members of the selected associations were randomly chosen.

Table 1: Sample description of respondents

\begin{tabular}{|c|c|c|c|c|c|c|c|c|c|c|c|}
\hline \multirow{4}{*}{$\begin{array}{l}\text { Population density } \\
\text { of residence }\end{array}$} & \multirow[b]{3}{*}{$<100,000$} & \multicolumn{4}{|c|}{ Currently not married } & \multicolumn{4}{|c|}{ Currently married } & \multirow{2}{*}{\multicolumn{2}{|c|}{ Total }} \\
\hline & & \multicolumn{2}{|c|}{ Female } & \multicolumn{2}{|c|}{ Male } & \multicolumn{2}{|c|}{ Female } & \multicolumn{2}{|c|}{ Male } & & \\
\hline & & 36 & $(69.2)$ & 16 & $(30.8)$ & 101 & $(41.7)$ & 141 & $(58.3)$ & 294 & [11.8] \\
\hline & $100-<200,000$ & 69 & $(62.2)$ & 42 & $(37.8)$ & 203 & $(51.8)$ & 189 & $(48.2)$ & 503 & {$[20.1]$} \\
\hline & $200-<500,000$ & 110 & $(65.9)$ & 57 & $(34.1)$ & 165 & $(44.1)$ & 209 & $(55.9)$ & 541 & [21.6] \\
\hline \multirow{2}{*}{\multicolumn{2}{|c|}{ Total }} & 289 & $(60.5)$ & 189 & $(39.5)$ & 374 & $(54.6)$ & 311 & $(45.4)$ & 1163 & [46.5] \\
\hline & & 504 & $(62.4)$ & 304 & $(37.6)$ & 843 & $(49.8)$ & 850 & $(50.2)$ & 2501 & {$[100]$} \\
\hline \multirow{3}{*}{$\begin{array}{l}\text { Been married } \\
\text { before } \\
\text { Total }\end{array}$} & No & 485 & $(60.9)$ & 311 & $(39.1)$ & 702 & $(48.6)$ & 743 & $(51.4)$ & 2241 & {$[92.8]$} \\
\hline & Yes & 30 & $(83.3)$ & 6 & $(16.7)$ & 71 & $(51.1)$ & 68 & (48.9) & 175 & {$[7.2]$} \\
\hline & & 515 & (61.9) & 317 & (38.1) & 773 & $(48.8)$ & 811 & $(51.2)$ & 2416 & {$[100]$} \\
\hline \multirow{3}{*}{$\begin{array}{l}\text { Spouse married } \\
\text { before } \\
\text { Total }\end{array}$} & No & & & & & 777 & $(48.8)$ & 816 & $(51.2)$ & 1593 & [93.5] \\
\hline & Yes & & & & & 65 & $(59.1)$ & 45 & $(40.9)$ & 110 & {$[6.5]$} \\
\hline & & & & & & 842 & (49.4) & 861 & $(50.6)$ & 1703 & [100] \\
\hline \multirow[t]{7}{*}{ Education level } & no formal educ & 1 & $(50.0)$ & 1 & $(50.0)$ & 12 & $(40.0)$ & 18 & $(60.0)$ & 32 & {$[1.2]$} \\
\hline & primary level & 4 & $(57.1)$ & 3 & $(42.9)$ & 58 & $(36.7)$ & 100 & $(63.3)$ & 165 & {$[6.3]$} \\
\hline & secondary form 3 & 3 & (33.3) & 6 & $(66.7)$ & 39 & $(33.3)$ & 78 & $(66.7)$ & 126 & [4.8] \\
\hline & secondary form 5 & 126 & $(55.8)$ & 100 & $(44.3)$ & 339 & $(53.6)$ & 294 & $(46.5)$ & 859 & {$[33.0]$} \\
\hline & diploma/STPM & 242 & $(66.1)$ & 124 & $(33.9)$ & 274 & $(52.0)$ & 253 & $(48.0)$ & 893 & [34.3] \\
\hline & Bachelors & 132 & $(63.8)$ & 75 & $(36.2)$ & 124 & $(52.8)$ & 111 & $(47.2)$ & 442 & {$[17.0]$} \\
\hline & Masters/PhD & 12 & $(54.6)$ & 10 & $(45.5)$ & 20 & $(32.3)$ & 42 & $(67.7)$ & 84 & [3.2] \\
\hline Total & & 520 & $(62.0)$ & 319 & (38.0) & 866 & $(49.2)$ & 896 & (50.9) & 2601 & {$[100]$} \\
\hline \multirow[t]{4}{*}{ Ethnic } & Malay & 281 & $(61.5)$ & 176 & $(38.5)$ & 641 & $(50.6)$ & 627 & $(49.5)$ & 1725 & [84.9] \\
\hline & Chinese & 41 & $(56.9)$ & 31 & $(43.1)$ & 47 & $(42.7)$ & 63 & $(57.3)$ & 182 & [9.0] \\
\hline & Indian & 27 & (77.1) & 8 & $(22.9)$ & 13 & $(39.4)$ & 20 & $(60.6)$ & 68 & [3.4] \\
\hline & other & 19 & $(59.4)$ & 13 & $(40.6)$ & 13 & $(52.0)$ & 12 & $(48.0)$ & 57 & [2.8] \\
\hline Total & & 368 & (61.7) & 228 & (38.3) & 714 & (49.7) & 722 & $(50.3)$ & 2032 & [100] \\
\hline \multirow[t]{3}{*}{$\overline{\text { Age }}$} & Mean & & 6.93 & & 6.85 & & 3.17 & & 2.27 & \multirow{3}{*}{\multicolumn{2}{|c|}{$\mathrm{N}=2603$}} \\
\hline & Minimum & & 18 & & 18 & & 20 & & 21 & & \\
\hline & Maximum & & 60 & & 65 & & 72 & & 75 & & \\
\hline \multirow[t]{3}{*}{ Income } & Mean & & 03.63 & & 71.21 & & 5.79 & & 62.22 & \multirow{3}{*}{\multicolumn{2}{|c|}{$\mathrm{N}=2357$}} \\
\hline & Minimum & & 0.00 & & 00.00 & & 0.00 & & 0.00 & & \\
\hline & Maximum & &, 000 & & 3,300 & & 000 & &, 000 & & \\
\hline
\end{tabular}

Notes: Numbers may not add up to the total size of the sample due to missing responses. (.) percentage within group; [.] percentage of total. 
The selected participants were given a choice to complete a written questionnaire either in English or in the national language, Bahasa Malaysia. Out of the targeted sample of 4050 respondents, 2653 usable completed and partially-completed questionnaires were obtained. Since the first objective of this study focuses on decision making within a household, in particular of husband and wife, the analysis is based on the information provided by respondents who were currently married at the time of the survey only. However, for the second objective which examines risk tolerance of men and women, the sample also includes those who were unmarried at the time of the survey. Table 1 presents a summary of the sample for this study. About 67.7 percent of the respondents were currently married at the time of the survey while the rest were unmarried, and 53.9 percent were males. Majority of the respondents were Malay (84.9 percent), with the remaining made up of Chinese, Indians, and other ethnicities. Although the percentage for Malays was disproportionately high, we suspect that the actual percentage may be lower since a significant number of respondents did not disclose their ethnicity. ${ }^{5}$ Over 46 percent of the respondents lived in areas with population density 500,000 or more, while 11.8 percent resided in areas with population less than 100,000. Slightly more than one half of them have their education higher than secondary school level of form 5. Among the married respondents and their spouses, more than 91.2 and 93.5 percent, respectively, were in their first marriage. Those who are currently married were, on average, older and earned higher incomes, than those who were not married at the time of the survey.

\section{FINDINGS}

\subsection{Financial Investment Decision Making}

In the survey, respondents were asked on who usually makes the decisions regarding their own financial investments. The possible responses were (i) mostly themselves; (ii) mostly their spouse: (iii) them and their spouse together; or (iv) other (than them or their spouse). Individuals who responded "other" were omitted from the analysis since the other three responses provide some order of ranking, and in addition, fewer than 5 respondents gave the latter response. A value of 1 is given if the response was mostly their own decision, 2 if they make joint decision with spouse, and 3 if their spouse makes the decision. t-tests on the means for the male and female respondents reveal that both are less than 2 , which implies that both men and women tend to make their own decisions regarding their financial investments. ${ }^{6}$ This result is consistent with Zimmer (2009) that increasingly women were consuming financial products independently and in conjunction with their spouses and partners.

Ordinal probit regressions on decision making for financial investment are estimated for the sample of married respondents only with a dummy variable Male equals to 1 if the respondent is a male. The variable earning share computed as the ratio of the respondent income to the

\footnotetext{
The sampling procedure was constructed in such a way that the ethnic groups would be proportionately represented (see note 2). The actual sample (of married and unmarried respondents) obtained did not reflect that due to the lack of willingness by some, perhaps more among the non-Malays, to participate in the survey, and the non-disclosure of information on ethnicity by some other respondents. The population estimates for 2007 are $66.7 \%$ Malay, $24.9 \%$ Chinese, $7.5 \%$ Indians and $1.2 \%$ others (Malaysia Department of Statistics, 2008).

6 The mean values for male and female respondents are 1.48 and 1.42 , and the $\mathrm{t}$-values obtained for the tests are -26.857 and -34.372 , respectively, which are both significantly less than 2 at the 1 percent level
} 
sum of the respondent and the spouse's income is used as a measure of bargaining power of the respondent in his/her household. Population density of the city or town a respondent lives in is included as an explanatory variable to differentiate between one who lived in an urban area and one who lived in non-urban area. Age, education level, income and ethnic group of the respondents are included to account for possible socio-economic effects. For ethnicity, two dummy variables are created, Malay takes the value of 1 if the respondent was a Malay, and Chinese takes the value of 1 if the respondent was a Chinese. Indians and other ethnic groups belong in the base category. The study also takes into account the effects of family structure, which are (i) whether the respondent and/or spouse has been married before, as considered by McConocha et al., (1993), which they termed it as non-traditional family, as opposed to a traditional one; and (iii) the number of children of the respondent. The findings are presented in Table 2, model 1.

Table 2: Ordinal probit regressions on decision-making on married respondents

\begin{tabular}{lcccc}
\hline & $\mathbf{1}$ & $\mathbf{2}$ & $\mathbf{3}$ & $\mathbf{4}$ \\
& All & Females & Males & All \\
\hline Age & $-0.013^{*}$ & -0.008 & $-0.018^{*}$ & -0.008 \\
Education & -0.073 & -0.093 & -0.050 & -0.067 \\
Malay & 0.2733 & 0.128 & $0.586 *$ & 0.289 \\
Chinese & -0.0393 & 0.229 & -0.283 & -0.031 \\
Male & -0.050 & & & -0.089 \\
Number of children & 0.035 & 0.0328 & 0.036 & 0.036 \\
Population density of residence & -0.041 & -0.0332 & -0.038 & -0.037 \\
Log(income) & 0.123 & 0.124 & 0.118 & 0.1157 \\
Earning share & $-1.030 * *$ & $-1.329 * *$ & -0.480 & $-1.3837 *$ \\
Respondent married before & -0.280 & -0.501 & 0.072 & -0.2797 \\
Spouse married before & -0.005 & 0.172 & -0.706 & -0.012 \\
Age*Male & & & & -0.0092 \\
Earning share*Male & & & & 0.7792 \\
Pseudo R-squared & 0.023 & 0.0175 & 0.053 & 0.024 \\
LR statistic & $28.178^{* *}$ & 13.386 & $25.275 * *$ & $30.165 * *$ \\
\hline
\end{tabular}

Note: $*$ and $* *$ significant at 5 and $1 \%$ levels, respectively.

Firstly, age is related to decision making in which older respondents, compared to their younger counterparts, are more likely to make their own decisions regarding their financial investments. Education, ethnicity, urbanicity and income are not important determinants of financial investment decision-making. There is also no gender difference in final decisions with regards to decision making on financial investments. Similarly, family structure, in terms of number of children and whether the respondents or their spouses had been married before do not significantly affect the final decision making. 
However, the decision-making process is affected by earning share. Respondents with higher earning shares are more likely to make decisions on their own financial investments. This finding is consistent with the bargaining model where increases in bargaining power that result from higher earning share lead to greater participation in the decision-making process.

A further examination is conducted to determine if the effects of age and earning share are different between married male and female respondents, or the effects are significant to only one gender. Ordinal probit models are estimated separately for female (Table 2, model 2) and male respondents (Table 2, model 3). In addition, another regression is estimated for all married respondents but including two interaction terms to account for these effects (Table 2, Model 4).

Age, in fact, significantly affects final decision making on financial investments for married male respondents only. Wald coefficient test on the sum of the coefficients of Age and Age*Male of model 4 indicates that it is significantly less than zero $(F$-statistic $=4.283)$ at the 5 percent level. The result implies that for men, the older ones are more likely to make their own financial investment decisions. However, for women, age is not an important factor in financial investment decision making.

A reverse finding is obtained for earning share. Earning share is a significant determinant for women, where women who have larger earning shares will more likely make their own decisions with regards to their financial investments. For men, earning share is not a significant factor based on Wald coefficient test on the sum of the coefficients of Earning share and Earning share $*$ Male of model $4(F$-statistic $=1.334)$.

\subsection{Risk Tolerance}

The second part of the analysis compares men and women's level of risk tolerance. There are essentially two ways to measure risk tolerance: (i) observed ratio of risky assets to wealth; or (ii) a stated (or subjective) measure based on household/individual response to a survey question asking how much financial risk the household/individual is willing to take (Jianakoplos and Bernasek, 2008). Jianakoplos (2002) showed that although contradictions could be found in the stated versus observed financial risk taking of households, the measures were consistent at the ordinal level. Studies that applied the first measure or variation of it include Shaw (1996), Friend and Blume (1975), Morin and Suarez (1983), Jianakoplos and Bernasek (1998), and Bernasek and Shwiff (2001), among others. The second measure was being used in studies such as Chaulk et al., (2003), Finke and Huston (2003), and Lai (2006). Other literature, for instance Jianakoplos and Bernasek (2008) applied both measures.

This study measures level of risk tolerance using the second method based on the response given to a question in the survey: "Which of these statements best describes the amount of financial risk that you are willing to take when you save or make investment?" A value of 1 is assigned to those who responded as "I take substantial financial risk expecting to earn substantial returns" or "I take above average financial risk expecting to earn above average return". A value of 2 is given for the response, "I take average financial risk expecting to earn 
average return", while a value of 3 is for the response "I take less than average financial risk expecting to earn a lower than average return" or "I am not willing to take any financial risk".

Although the survey also included questions on the types and corresponding values of financial assets owned by respondents, many of them did not complete these questions. For those who did, we suspect that many under-reported the value of their assets, since these type of information are sensitive and very private to most Malaysians. Due to this circumstance, only the second measure is used in this study. In addition, as explained by Deaves et al. (2007), although some argued that actual decisions are preferable to stated preferences, in reality neither is perfect. For asset allocations to accurately reflect investor risk attitudes requires that investors be knowledgeable about such things as the historical variance of various asset classes, portfolio theory, and the use of systematic risk as a risk measure. Moreover, the use of asset allocations to indicate risk preferences assumes that investors can accurately operationalize the aforementioned knowledge.

The analysis is conducted by estimating ordinal probit regressions with a dummy variable Male equal to 1 if the respondent is a male, to account for gender differences. The regression models also include other factors which can affect risk tolerance such as education and income or wealth (Dwyer et al., 2002; Al-Ajmi, 2008), race or ethnicity (Jianakoplos and Bernasek, 1998), and age (Deaves et al., 2007; Al-Ajmi, 2008) as control variables in addition to the population density of the area the respondent lives in.

Previous studies found that the level of risk tolerance differs between women who are single and married (Jianakoplos and Bernasek, 1998; Riley and Chow, 1992), and the effect of wealth were different between single and married persons (Jianakoplos and Bernasek, 1998). Hence, regressions are estimated for the whole sample (Table 3, model 1), and then separately for unmarried and married respondents, unmarried women, unmarried men, married women and married men (Table 3, models 2-4, 6-8). In addition, for married men and women, three additional regressions are estimated (models $5,9,10)$ to include other variables such as earning share to represent bargaining power of the individual, the number of children of the respondent (as found to be significant by Jianakoplos and Bernasek, 1998), and spouses who were previously married (as shown to be an important determinant by Woolley, 2003).

The results as presented in Table 3, model 1 show that male respondents have higher levels of risk tolerance as compared to female respondents. Overall, older respondents are more risk averse than the younger ones, while those with higher education or living in more urban areas tend to be less risk averse. An examination on the regressions for specific groups reveals that the effects of the socioeconomic variables are different between males and females, and between those who were married and not (models 2-10). The estimates also indicate that bargaining power and family structure variables have no significant effects on the level of risk tolerance.

Another ordinal probit model is estimated for all respondents, but including interaction terms to account for differences between groups (model 11). Wald tests on the coefficients are applied and some interesting findings are found. Firstly the level of risk tolerance decreases with age 


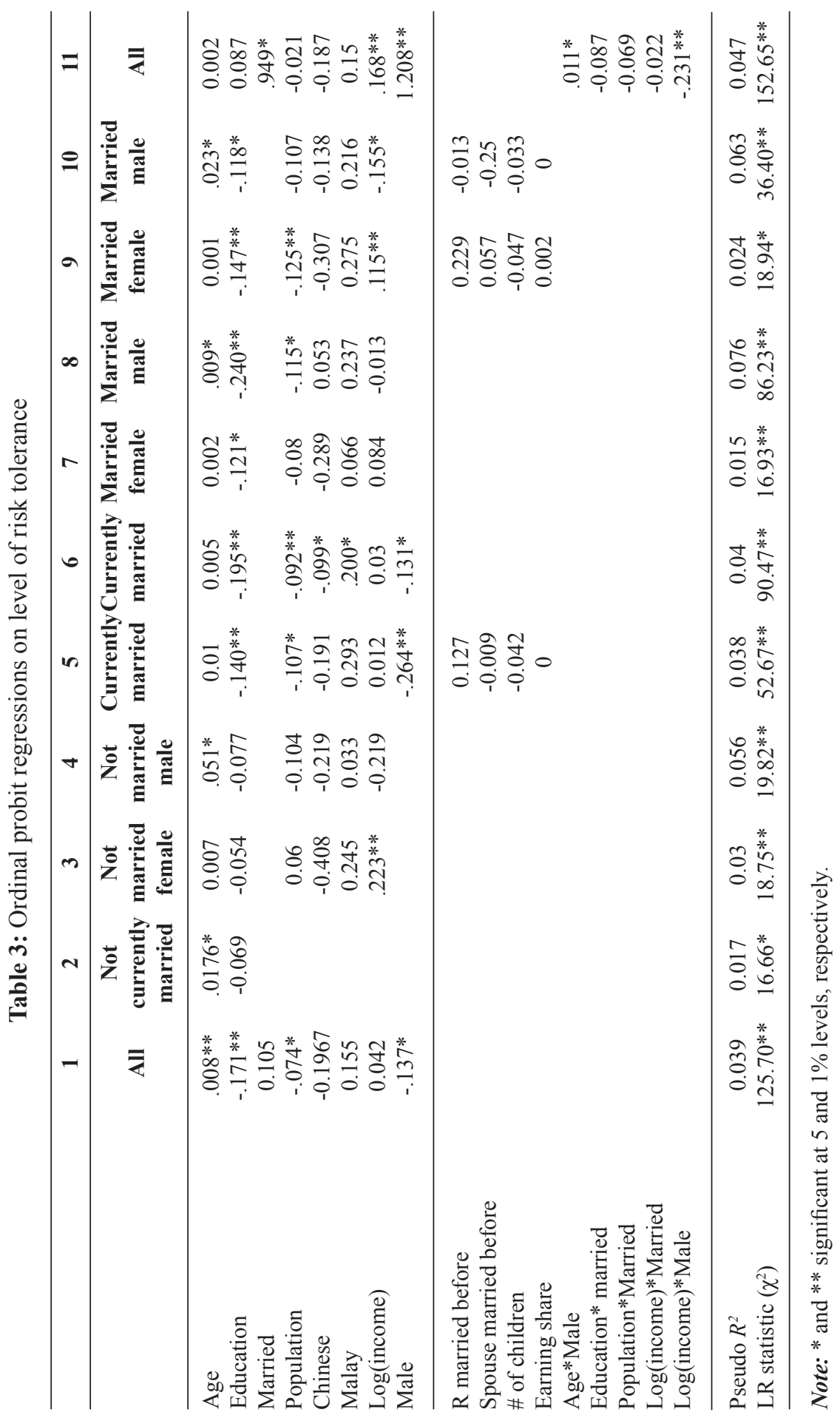


for men, but age has no significant effect on risk tolerance for women. Secondly, the level of education is an important determinant for only those who were married. Married respondents who have higher levels of education tend to be more risk tolerant than those who have lower education levels. Thirdly, and lastly, a higher income level increases the risk tolerance of women, but not of men.

\section{CONCLUSIONS}

This study uses data from a recent survey to examine final decision-making and level of risk tolerance of employed men and women in Malaysia. The results on decision making using ordinal probit regressions are consistent with the predictions of the bargaining model. Married men and women respondents tend to make their own decisions regarding these investments. Age and earning share are variables that significantly affect decision making for specific groups of respondents. Specifically, age is an important factor for men, where the older they are, the more likely they are going to make their own decisions on their financial investments. Earning share is a significant determinant for women, where those who have a larger earning share will more likely make their own financial investment decisions.

The analysis also shows that male respondents have higher levels of risk tolerance than female respondents. Similar to financial investment decision making, age is a significant factor in the level of risk tolerance for men, but not for women. However, earning share does not significantly affect risk tolerance level of married men or women. On the other hand, education and income are important determinants for those who were married and for women, respectively, where higher levels of education and income imply more tolerance to risk.

Some implications can be derived from this study. In Malaysia, all private sector employees, and public sector employees who have opted for it, must be a member of the Employees Provident Fund (EPF) where together with their employers contribute a certain percentage of their monthly salary to the fund..$^{7}$ The total contribution can only be withdrawn upon reaching the retirement age, typically at 55 years old, or earlier if the member is no longer fit to work. Legally, the EPF is obligated to provide 2.5 percent dividends, but actual dividend payouts have been higher. For instance, the declared annual dividend for 2009 was 5.65 percent. Beginning November 1996, the scheme allows members who surpass a minimum amount of total savings to invest part of their savings through external fund managers approved by the Malaysian Ministry of Finance. Thus, Malaysians, and in particular women's well-being in retirement depends to some extent on their attitudes towards risk and the impact of those attitudes on investment decisions made on their EPF savings. The more conservative investment tendencies of women may lead to lower investment returns, and smaller retirement income.

This situation may tend to exacerbate due to Malaysia leaning towards becoming an aging population. The percentage of Malaysian population 65 years or more has increased steadily over the years, from 3.54 percent in 1980 to 4.71 percent in $2010 .^{8}$ This upward trend is

\footnotetext{
http://www.kwsp.gov.my/index.php?lang=en.

8 http://www.statistics.gov.my/portal/download_Population/files/BPD/msia_broadage_1963-2010.pdf
} 
expected to persist with the crude birth and death rates have been decreasing at, respectively, 30.6 and 5.3 percent for 1980 and 18.1 and 4.5 percent for 2007. Men and women's life expectancies have also increased from 66.4 and 70.7 years in 1980 to 71.5 and 76.3 years in 2006, respectively. ${ }^{9}$ The potential social burden of those entering retirement with inadequate financial resources could have a profound impact on the economy.

With women earning higher incomes and increasingly more likely to have bigger household earning shares, they are becoming major players in the financial investment sphere. Knowledge on financial markets and investments is essential to ensure that women make wise and proper decisions regarding their financial investments. This is especially so due to their greater need for retirement income with their increased longevity. Educational investment marketing effort must be tailored to the needs and preferences of women since it has been shown their investment behavior differs from that of men.

It must be noted that the findings and implications of this study must take into consideration the limitation of the research. First, the sample of employed men and women used in this study may not necessarily represent the Malaysian population, in general. In addition, as stated in the earlier section, the proportions according to ethnicity in the sample do not reflect the population. Another limitation is that own financial investment, instead of household financial investment, is used to test on the two theories of household decision-making process. Nevertheless, the differences in risk tolerance behavior between married men and women, and variations in the effects of age and income on men and women strengthen the results obtained from the analysis on decision-making. However, further research should address these limitations to determine if these findings are confirmed among the population more generally.

\section{ACKNOWLEDGEMENT}

This paper is based on a bigger project entitled, "Expenditure and Investment Patterns of Malaysians," funded by Yayasan Tun Mohamed Ismail Ali Berdaftar, Permodalan Nasional Berhad. I gratefully acknowledge their support and cooperation.

\section{REFERENCES}

Al-Ajmi, J. Y. (2008). Risk tolerance of individual investors in an emerging market. International Research Journal of Finance and Economics, 17, 15-26.

Barber, B. M., \& Odean, T. (2000). Trading is hazardous to your wealth: The common stock investment performance of individual investors. Journal of Finance, 55(2), 773-806.

Becker, G. S. (1974). A theory of marriage. In T. W. Schultz (Eds.), Economics of the Family. Chicago: University of Chicago Press.

Malaysia Department of Statistics, http://www.statistics.gov.my/portal/download_Economics/files/DATA_SERIES/2009/ Bab_21Perangkaan_Penduduk.pdf 
Becker, G. S. (1981), A Treatise on the Family. Cambridge MA: Harvard University Press.

Beckmann, D., \& Menkhoff, L. (2008). Will women be women? Analyzing the gender differences among financial experts. Kyklos, 61(3), 364-384.

Bernasek, A., \& Bajtelsmit, V. L. (2002). Predictors of women's involvement in household financial decision-making. Financial Counseling and Planning, 13(2), 39-47.

Bernasek, A., \& Shwiff, S. (2001). Gender, risk, and retirement. Journal of Economic Issues, 35(2), 345-356.

Beyer, S., \& Boweden, E. M. (1997). Gender differences in self-perceptions: Convergent evidence from three measures of accuracy and bias. Personality and Social Psychology Bulletin, 23(2), 147-72.

Blumstein, P. W., \& Schwartz, P. (1983). American Couples: Money, Work, Sex. New York, NY: William Morrow.

Bruce, A., \& Johnson, J. (1994). Male and female betting behavior: new perspective. Journal of Gambling Studies, 10(2), 183-98.

Burgoyne, C., \& Morison, V. (1997). Money in re-marriage: keeping things separate - but simple. Sociological Review, 45(3), 363-395.

Chaulk, B., Johnson, P., \& Burcroft, R. (2003). Effects of marriage and children on financial risk tolerance: A synthesis of family development and prospect theory. Journal of Family and Economic Issues, 24(3), 257-279.

Commuri, S., \& Gentry, J. W. (2005). Resource allocation in households with women as chief wage earners. Journal of Consumer Research, 32(September), 185-195.

Davis, H. L., \& Rigaux, B. P. (1974). Perception of marital roles in decision process. Journal of Consumer Research, 1(1), 51-62.

Deaves, R., Veit, E. T., Bhandari, G., \& Cheney, J. (2007). The savings and investment decisions of planners: A cross-sectional study of college employees. Financial Services Review, 16, 117-133.

Doss, C. (1996). Testing among models of intrahousehold resource allocation. World Development, 24(10), 1597-1609.

Dwyer, P. G., Gilkeson, J. H., \& List, J. A. (2002). Gender differences in revealed risk taking: evidence from mutual fund investors. Economics Letters, 76(2), 151-158.

Estes, R., \& Hosseini, J. (1988). The gender gap on Wall Street: An empirical analysis of confidence in investment decision-making. The Journal of Psychology, 122(6), 577-90.

Finke, M., \& Huston, S. (2003). The brighter side of financial risk: Financial risk tolerance and wealth. Journal of Family and Economic Issues, 24(3), 233-256. 
Ford, J. B., LaTour, M. S., \& Henthorne, T. L. (1995). Perception of marital roles in purchase decision processes: a cross-cultural study. Journal of the Academy of Marketing Science, 23(2), 120-131.

Friend, I., \& Blume, M. (1975). The demand for risky assets. American Economic Review, $65(5), 900-922$.

Gervais, S., \& Odean, T. (2001). Learning to be overconfident. Review of Financial Studies, 14(1), 1-27.

Goode, J., Callender, C., \& Lister, R. (1998). Purse or wallet? Gender inequalities and income distribution within families on benefits. Policy Studies Institute: London, UK.

Hershey, J., \& Schoemaker, P. (1980). Risk taking and problem context in the domain of losses: An expected utility analysis. Journal of Risk and Insurance, 47(1), 111-132.

Hinz, R., McCarthy, D., \& Turner, J. (1997). Are women more conservative investors? Gender differences in participant directed pension investments. In M. Gordon, O. Mitchell, \& M. Twinney (Eds.), Positioning Pensions for the Twenty-First Century. Philadelphia, PA: PRC.

Jianakoplos, N. A. (2002). Invest as I say, not as I do? Gender differences in financial risk preferences. International Business and Economics Research Journal, 1(1), 1-8.

Jianakoplos, N. A., \& Bernasek, A. (1998). Are women more risk averse? Economic Inquiry, 36(4), 620-630.

Jianakoplos, N. A., \& Bernasek, A. (2008). Family financial risk taking when the wife earns more. Journal of Family and Economic Issues, 29, 289-306.

Kanbur, R., \& Haddad, L. (1994). Are better off households more unequal or less unequal: A bargaining theoretic approach to 'Kuznets effects' at the micro level, Oxford Economic Papers, 46(3), 445-458.

Lai, C. W. (2006). Determinants of portfolio efficiency losses in U.S. self-directed pension accounts. Journal of Family and Economics Issues, 27(4), 601-625.

Laurie, H., \& Rose, D. (1994). Divisions and allocations within households. In N. Buck, J. Gershuny, D. Rose, \& J. Scott (Eds.), Changing households: The British household panel survey 1990-92. Colchester, UK: University of Essex.

Lee, C. K. C., \& Beatty, S. E. (2002). Family structure and influence in family decision making. Journal of Consumer Marketing, 19(1), 24-41.

Lewellen, W., Lease, R., \& Schlarbaum, G. (1977). Patterns of investment strategy and behavior among individual investors. Journal of Business, 50(3), 296-333.

Lundberg, S. J., \& Pollak, R. A. (1993). Separate spheres bargaining and the marriage market. Journal of Political Economy, 101(6), 988-1010. 
Lundberg, S. J., Pollak, R. A., \& Wales, T. J. (1997). Do husbands and wives pool their resources? Evidence from the United Kingdom child benefit. The Journal of Human Resources, 32(3), 463-480.

Lundeberg, M., Fox, P., \& Punccohar, J. (1994). Highly confident but wrong: Gender differences and similarities in confidence judgment. Journal of Educational Psychology, 86(1), 114-121.

Malaysia Department of Statistics. (2008). Yearbook of Statistics Malaysia 2007. Kuala Lumpur, Malaysia: Department of Statistics.

Malaysia Department of Statistics. (2010). Key indicator of the labour market, Malaysia 20012009 (Series 3, No. 1/2010). Retrieved, July 8, 2010, from http://www.statistics.gov.my/ portal/download_Labour/files/BPTMS/indikator_0109.pdf.

Malone, K., Stewart, S. D., Wilson, J., \& Korsching, P. F. (2010). Perceptions of financial wellbeing among American women in diverse families. Journal of Family and Economic Issues, 31(1), 63-81.

Manser, M., \& Brown, M. (1980). Marriage and household decision making: a bargaining analysis. International Economic Review, 21(1), 21-30.

Martinez, E., \& Polo, Y. (1999). Determining factors in family purchase behavior: An empirical investigation. Journal of Consumer Marketing, 16(5), 461-481.

McConocha, D. M., Tully, S. A., \& Walther, C. H. (1993). Household money management: Recognizing nontraditional couples. The Journal of Consumer Affairs, 27(2), 258-283.

McElroy, M., \& Horney, M. J. (1981). Nash bargained household decisions. International Economic Review, 22(2), 333-350.

Morin, R. A., \& Suarez, F. (1983). Risk aversion revisited. Journal of Finance, 38(4), 12011216.

Pahl, J. (1995). His money, her money: Recent research on financial organization in marriage. Journal of Economic Psychology, 16(3), 361-376.

Pahl, J. (2000). Couples and their money: Patterns of accounting and accountability in the domestic economy. Accounting, Auditing \& Accountability Journal, 13(4), 502-517.

Phipps, S. A., \& Burton, P. S. (1998). What's mine is yours? The influence of male and female incomes on patterns of household expenditure. Economica, 65(260), 599-613.

Riley, W. B., \& Chow, K. V. (1992). Asset allocation and individual risk aversion. Financial Analysts Journal, 48(6), 32-37.

Samuelson, P. A. (1956). Social indifference curves. Quarterly Journal of Economics, 70(1), 1-21. 
Schubert, R. (2006). Analyzing and managing risks - on the importance of gender differences in risk attitudes. Managerial Finance, 32(9), 706-715.

Schubert, R., Brown, M., Gysler, M., \& Brachinger, H. W. (1999). Financial decision-making: Are women really more risk-averse? American Economic Review, 89(2), 381-385.

Shaw, K. (1996). An empirical analysis of risk aversion and income growth. Journal of Labor Economic Review, 14(4), 626-653.

Stinerock, R., Stern, B., \& Solomon, M. (1991). Sex and money: Gender differences in the use of surrogate consumers for financial decision making. Journal of Professional Services Marketing, 7(2), 167-182.

Sunden, A., \& Surette, B. (1998). Gender differences in the allocation of assets in retirement savings plans. American Economic Review, 88(2), 207-212.

Tichenor, V. J. (1999). Status and income as gendered resources: The case of marital power. Journal of Marriage and the Family, 61(3), 638-650.

Times Publishing Group. (2004). Times Business Directory of Malaysia 2004, $10^{\text {th }}$ ed. Shah Alam, Malaysia: Times Trade Directories.

Vogler, C., \& Pahl, J. (1993). Social and economic change and the organization of money in marriage. Work, Employment and Society, 7(1), 71-95.

Vogler, C., \& Pahl, J. (1994). Money, power and inequality within marriage. Sociological Review, 42(2), 263-288.

Webster, C. (1994). Effects of Hispanic ethnic identification on marital roles in the purchase decision process. Journal of Consumer Research, 21(2), 319-31.

Woolley, F. (2003). Control over money in marriage. In S. A. Grossbard-Schechtman (Eds.), Marriage and the Economy. Cambridge: Cambridge University Press.

Yilmazer, T., \& Lyons, A. C. (2010). Marriage and allocation of assets in women's defined contribution plans. Journal of Family and Economic Issues, 31(2), 121-137.

Zimmer, D. M. (2009). Insurance arrangements among married couples: Analysis of benefit substitution and compensating differentials. Journal of Family and Economic Issues, $30(4), 428-439$.

Zinkhan, G., \& Karande, K. (1991). Cultural and gender differences in risk taking behavior among American and Spanish decision-makers. Journal of Social Psychology, 131(5), 741-742. 